\title{
Abordarea interdisciplinară a despicăturilor facio-labio-palatine
}

\author{
Ioana Mădălina ORIAN ${ }^{1}$
}

\begin{abstract}
Labio-maxillo-palatine clefts represent the most common congenital anomaly of all congenital malformations of the face and they are the most frequent cause of rhinolic disorders. The complexity of the therapeutic approach is determined by nutrition and eating problems, hearing and ENT problems, dento-facial and orthodontic abnormalities, breathing disorders, phonation disorders, reduced speech intelligibility, various physiognomic disorders.

The presented case study emphasizes the need of an interdisciplinary approach to labio-maxillo-palatine clefts and follows the recovery process from a multidisciplinary perspective. The conclusions of the paper support the idea that the recovery process of the child with facio-labio-palatine cleft is a complex, long-termed one and the concern of the speech and language therapist to expand his field of activity is justified because this disorder involves pre and post surgery intervention and the therapist supports the entire process in all the mentioned areas.
\end{abstract}

Keywords: labio-maxillo-palatine cleft, open rhinolalia, orthodontic devices, speech intelligibility, speech disorder

\section{Introducere}

În ultimii ani se poate observa o preocupare în vederea extinderii domeniului de activitate a terapeutului limbajului, existând o legătură tot mai strânsă între intervenția în reabilitarea limbajului, domeniul ORL și intervenția în cazul tulburărilor de alimentație (băut, mâncat, înghițit).

În 2015, ASHA (American Speech Language Hearing Association) delimitează domeniul practicii logopedice, în ceea ce privește tulburările de limbaj și vorbire întâlnite la copii, astfel (Bodea Hațegan, 2016):

Tulburări de vorbire: apraxia, bâlbâiala, dizartria, tulburările de voce, tulburările miofuncționale de la nivel orofacial, tulburările sunetelor vorbirii (tulburările de pronunție și fonologice);

Tulburări de limbaj: dificultăți specifice de învățare, tulburări de limbaj apărute la vârsta preșcolarității, mutism electiv;
Patologii medicale care implică tulburări de limbaj și vorbire: ADHD, tulburarea din spectrul autist, despicăturile facio-labiopalatine, traumatismele craniene, afectarea emisferei cerebrale drepte.

\section{Direcții de cercetare}

\section{Despicăturile facio-labio-palatine}

Despicăturile labio-maxilo-palatine reprezintă cea mai frecventă anomalie congenitală dintre toate malformațiile congenitale ale feței, care pot să apară în cadrul unor sindroame genetice sau pot fi izolate, adică neasociate unei alte boli (Tote et al, 2014) și reprezintă cauza cea mai frecventă pentru tulburările rinolalice (Bodea Hațegan, 2016).

Despicăturile constituie o provocare și o serioasă problemă medicală prin prisma varietăților de forme clinice pe care le îmbracă, a tulburărilor funcționale asociate, a tratamentului complex și special pe care îl necesită și a managementului terapeutic extrem de 
complex și divers (Burlibașa, 1999), care se desfășoară pe o perioadă îndelungată de timp și care include în mod obligatoriu o echipă multidisciplinară.

\section{Greșterea și dezvoltarea cranio-facială}

Despicăturile labio-maxilo-palatine reprezintă tulburări ale aparatului dentomaxilar care apar ca fiind anormale în cadrul procesului de dezvoltare craniofacială, proces care are loc în primele săptămâni de viață intrauterină.

Principalele etape ale dezvoltării craniofaciale cuprind:

Formarea mugurilor faciali, la sfârșitul celei de-a patra săptămâni de viață intrauterină. Această etapă este ulterior completată de formarea mugurilor nazali;

Formarea buzei superioare și a palatului primar. Dacă în această etapă nu se produce alipirea celor doi muguri maxilari sau este incompletă, poate să apară despicătura labială;

Formarea palatului secundar, care formează planșeul foselor nazale și plafonul cavității orale. În partea anterioară, acesta cuprinde palatul dur iar palatul moale se află în poziție posterioară iar acesta reprezintă o componentă esențială pentru o respirație normală, masticație, deglutiție și vorbire (Wyszynski, D.F., 2002).

Dacă oricare dintre etape nu se desfășoară, total sau parțial, așa cum este firesc, apar diversele forme ale despicăturilor labiomaxilo-palatine. Mult timp s-a încercat să se descopere care sunt cauzele care stau la baza producerii despicăturilor, s-au elaborat multe și variate teorii, însă nici una nu a prezentat o explicație a cauzelor și a mecanismelor care produc aceste anomalii congenitale. Se pare că, ele sunt cauzate de interacțiunea mai multor factori, non-genetici sau/și genetici.

Formele pe care le poate lua despicătura sunt diverse și particulare fiecărui caz dar oricare dintre următoarele componente poate fi afectată: buze, prag narinar, creastă alveolară, palatul dur, vălul palatin, lueta, fiind prezentă în multe dintre cazuri comunicare între fosele nazale și cavitatea orală.

Copiii cu despicătură prezintă adesea diverse anomalii dentare, care par a nu exista la fel de frecvent în cazul copiilor care nu suferă de această afecțiune. Printre anomaliile cele mai frecvente se numără: modificări de număr (incluzii, hipodonții, dinți supranumerari) și modificări de formă. Dimensiunea dinților e mai mică la copiii cu despicătură iar cei mai mici dinți sunt reprezentați de cei cu despicătură palatină. Prezența unui dinte supranumerar pe partea afectată e a doua cea mai întâlnită anomalie dentară (Tote et al, 2014).

O particularitate observată la copiii cu despicături, care influențează mult demersul logopedic, o reprezintă retrognația maxilară. Un timp, această caracteristică de creștere și dezvoltare s-a pus pe seama țesutului cicatricial rezultat în urma intervenției chirurgicale, retrognația maxilară apărând ca secundară operației de reconstrucție. Dar, numeroase studii efectuate în ultimul timp, care s-au efectuat atât pe pacienți operați cât și pe cei neoperați, arată că pacienții cu despicătură prezintă mecanisme intrinseci de dezvoltare care determină o rată mai mică de creștere a maxilarului. Astfel, copiii cu despicătură prezintă etajul inferior al feței mai mic, 
înălțimea și lungimea maxilarului superior cu dimensiuni mai mici față de media normală. (Bjork, 2007; Saperstein, 2012).

S-a insistat în prezentarea detaliată a tipurilor și formelor pe care această afecțiune o poate da pentru a scoate în evidență particularitățile pe care le prezintă asupra fiecărui caz și pentru a sublinia faptul că fiecare intervenție chirurgicală presupune o nouă adaptare la noile posibilități articulatorii pe care intervenția o oferă și efectele psihologice ale intervenției asupra structurării personalității care determină deschiderea și motivarea copilului spre terapia logopedică.

\section{Intervenții terapeutice la copiif cu despicături}

Complexitatea și diversele forme pe care le poate lua această afecțiune necesită o abordare interdisciplinară, managementul terapeutic este unul complex, de lungă durată și necesită o echipă multidisciplinară din care fac parte: medic pediatru, chirurg maxilo-facial, specialist ortodont, logoped, psiholog, medic specialist psihiatrie pediatrică, ORL-ist, anestezist.

În acest moment, nu există o schemă fixă de tratament pentru tratarea despicăturilor, existând două protocoale terapeutice diferite: protocolul chirurgical Milan și protocolul chirurgical Oslo (Meazzini, 2008). Fiecare caz este unic, de aceea întreaga intervenție este puternic individualizată și necesită control și supraveghere adecvată pe toată durata tratamentului.

Diagnosticarea despicăturii labiale se poate realiza ecografic după primele 16 săptămâni de sarcină. Despicătura palatină este mai greu de observat prin această metodă (Shaikh et al, 2001). Discuția cu chirurgul și planificarea intervenției se poate realiza prenatal, după realizarea diagnosticării prin ecografie. Începând cu primul moment de viață al copilului, se vor utiliza tetine speciale pentru hrănirea sugarului (Miloro et al, 2004). Hrănirea sugarului și monitorizarea permanentă a greutății este importantă pentru intervențiile chirurgicale ulterioare. O greutate și o dezvoltare corespunzătoare ajută copilul să facă față operațiilor chirurgicale (Hurubeanu, 2002).

\section{Tratamentul ortodontic în cazul despicăturilor labio-maxilo-palatine}

În cazul despicăturilor labio-maxilopalatine se recomandă tratament ortodontic precoce, încă din primele săptămâni de viață. Tratamentul ortodontic este extrem de important și însoțește toate procedurile managementului terapeutic al despicăturilor labio-maxilo-palatine. Tratamentul ortodontic a fost împărțit în 4 etape: tratarea ortodontică a nounăscutului, dentiția temporară, dentiția mixtă, dentiția permanentă. Obiectivul tratamentului ortodontic este repoziționarea corespunzătoare a fragmentelor de maxilar separate și dislocate datorită funcțiilor patologice (discontinuitatea musculaturii labiale și interpunerea limbii în fisură)(Mercado A., Vig, K., 2019).

Tratamentul ortodontic pre-chirurgical se aplică înaintea corecției primare a despicăturii labiale (Salyer K. E., 2001) și ajută la remodelarea narinei, pentru apropierea segmentelor buzei sau a arcadei dentare. 
În tratamentul ortodontic pre-chirurgical se folosesc diverse plăci care au rol în:

-Ameliorarea condițiilor pentru corectarea chirurgicală ulterioară;

- Împiedică pătrunderea limbii în fisură;

-Favorizează apropierea fragmentelor maxilare;

-Se ușurează alimentația sugarului.

Repararea primară a despicăturii labiale are loc după primele 12 săptămâni de viață (Kirschner R. E., LaRossa D., 2000). Repararea primară a despicăturii palatine, cu veloplastie se realizează după primele 6-12 luni (Arosarena O. A., 2007). Se realizează tratament ortodontic pentru expansiunea maxilarului pentru dentiția temporară și tratament ortodontic pentru expansiunea maxilarului și avansarea acestuia pentru dentiția mixtă (Shetye P. R., 2012).

Rinoplastia se realizează după vârsta de 5 ani (Katzel E. B. et al, 2009) iar grefa osoară înaintea erupției dinților permanenți (Miloro M. et al, 2004, LevyBercowski D. et al., 2011). Tratamentul ortodontic pentru alinierea arcadelor se face pe dentiția permanentă (Boyne P. J., Sands N. R., 1972).

Chirurgia ortognată se referă la operațiile la nivelul maxilalelor practicată de un medic chirurg maxilo-facial. Operația este efectuată în cazul defectelor scheletale cu o ocluzie dentară incorectă, care nu poate fi rezolvată doar prin tratament ortodontic de îndreptare a dinților. Oasele maxilare pot fi dezvolte în exces sau deficitar. Scopul este deci de a rezolva mușcătura și de a reda pacienților un aspect facial plăcut și armonios dar și de a îmbunătăți respirația în timpul somnului prin lărgirea
pasajului
aerian
superior.
(dentalconceptstudio.ro)

Chirurgia ortognată pentru avansarea maxilarului se realizează după erupția dinților permanenți, alinierea arcadelor și terminarea creșterii (Shetye P. R., 2012) iar tratamentul ortodontic post-chirurgical pentru închiderea spațiilor reziduale și ultimele ajustări ale ocluziei (KuijpersJagtman A. M., 2006) precum și eventualele reconstituiri protetice (Vlachos C. C., 1996) se execută după intervenția de chirurgie ortognată.

În toată perioada de recuperare a copilului cu despicătură labio-maxilo-palatină, în tratamentul ortodontic, la aprecierea specialistului ortodont, se utilizează plăci palatinale, plăci linguale, gutiere, plăci de dilatare transversală utilizate în maxilarul îngust, aparate fixe și/sau mobile și aparate extraorale. Aparatele extraorale se utilizează în tratamentul precoce al prognatismului mandibular, în dentația temporară sau mixtă incipientă. Rolul lor este de inhibare a creșterii anterioare a mandibulei.

\section{Aspecte ale demersului terapiei logopedice}

Despicăturile labio-maxilo-palatine pot determina dezechilibrul mușchilor orofaciali, determinat de cauzele organice și funcționale specifice, precum și respirație orală cu postura anormală a limbii cauzată de problemele de natură ORL (de exemplu otita medie seroasă întâlnită frecvent în cazul acestei afecțiuni) sau malocluzie determinată de alterarea structurii dentale și scheletice. Acest dezechilibru muscular orofacial are ca și consecință defecte de pronunție a diferitelor sunete $(b, p, m ; d, t, n ; l, r ; s, z$, s, ț). 
Deglutiția este actul motor prin care bolul alimentar ce s-a format în cavitatea bucală străbate faringele și esofagul pentru a ajunge în stomac (Mureșan, R. 2015). În funcție de zona traversată de bolul alimentar există trei timpi ai deglutiției: bucal, faringian și esofagian. În cazul despicăturilor labio-maxilo-palatine, timpul bucal al deglutiției poate fi puternic afectat deoarece organele cuprinse în acest proces sunt afectate: buze, dinți, mandibulă, limbă. Timpul bucal afectat poate determina alterarea celorlalți timpi bucali, deglutiția fiind astfel deficitară și realizându-se îngreunat.

Diferențierea respirației orale de cea nazală și a respirației verbale de cea nonverbală reprezintă un prim obiectiv în terapie.

Indiferent de forma rinolaliei determinate de despicătură, reușita intervenției logopedice se bazează pe (Bodea Hațegan, 2016) :

- Dezvoltarea preachizițiilor;

- Dezvoltarea abilităților respiratorii;

- Dezvoltarea abilităților de diferențiere auditiv-verbală;

-Dezvoltarea abilităților motorii generale și fine.

Copiii născuţi cu despicătură unilaterală totală se confruntă cu probleme complexe de sănătate și cu o serie de tulburări funcționale. Dintre acestea se pot aminti:

Probleme de nutriţie și alimentație: părinţii se confruntă cu dificultăţi de hrănire a copilului, unii dintre copii au dificultăţi ale alimentaţiei la sân, având nevoie de tetină specială; reflux nazal al lichidelor şi alimentelor moi, uneori şi ale solidelor (regurgitare nazală);
Probleme auditive şi ORL: dificultăţi ale respiraţiei; complicaţii la nivelul urechii medii, apariția de otite seroase, acumulare de lichid în urechhea medie care poate duce la degradarea treptată a auzului cu afectarea auzului fonematic; infecţii respiratorii superioare frecvente (răceli, sinuzite);

Anomalii dentofaciale şi ortodontice: reconstrucția aparatului fonoarticulator; buza superioară rigidă; nevoia unui aparat de modelare a narinei încă de la primele săptămâni de viaţă; nevoia aparatelor dentare pentru corecția poziţiei vicioase a incisivilor de pe maxilarul superior dar şi a maxilarului;

Tulburări de respirație (nu diferențiază respirația orală de cea nazală, volumul respirator este afectat, respirația este preponderent superficială, toracală) (Bodea Hațegan, 2016);

Tulburări de fonație (vocea puternic nazalizată);

Reducerea inteligibilității verbale din cauza faptului că sunt afectate majoritatea sunetelor, mai puțin sunetele nazale (Bodea Hațegan, 2016);

Diverse tulburări fizionomice.

Terapia logopedică în cazul copiilor cu despicătură labio-maxilo-palatală se realizează în două etape: etapa preoperatorie și etapa postoperatorie. Reabilitarea preoperatorie câștigă din ce în ce mai mult teren în medicină și se referă la pregătirea pacienților pentru tratamente programate și intervenții, având ca scop acela de a reduce riscurile și complicațiile, ajutând la refacerea mai rapidă a acestora (intramed.ro). Etapa logopedică preoperatorie este esențială și 
se stabilește nivelul preachizițiilor și presupune parcurgerea terapiei logopedice clasice, fără a insista asupra emiterii, consolidării și automatizării sunetele. (Guțu, 1974; Moldovan, 2006)

\section{Pozitia ASHA referitoare la despicăturile labio-maxilo-palatine}

ICF (International Classification of Functioning, Disability and Health) este o clasificare a sănătății și a condițiilor legate de sănătate pentru copii și adulți care a fost elaborată de către Organizația Mondială a Sănătății (OMS) și publicată în 2001. Cadrul clasificării poate fi utilizat în practica de colaborare interprofesională și în îngrijirea centrată pe persoană. Acest cadru propune abordarea dizabilității unei persoane în contextul funcționării acesteia la activitățile individuale și a participării la viața de zi cu zi.

Ce sunt obiectivele funcționale bazate pe persoană? Sunt obiective identificate de către client, împreună cu terapeutul, clinicianul și familia, care permit participarea persoanei la activități pline de semnificație și având roluri importante. Aceste obiective se folosesc pentru a valoriza la maxim rezultatele care duc la îmbunătățiri semnificative în ceea ce privește funcționalitatea individului; de a optimiza potențialul persoanei $\mathrm{cu}$ dizabilități având în vedere participarea la activități semnificative; pentru a facilita un parteneriat care să asigure individului și familiei dreptul la opinie în îngrijirea primită și rezultatele obținute; să demonstreze plătitorilor valoarea serviciilor oferite.

În ceea ce privește despicăturile faciolabio-palatine obiectivele se stabilesc din perspectiva următoarelor aspecte:
-Starea de sănătate: tulburarea sau boala care oferă comorbiditățile și prognosticul;

-Funcțiile și structurile corpului: părțile anatomice și funcțiile lor fiziologice;

-Activități și participare: executarea sarcinilor sau implicarea în situații de viață;

-Factori de mediu și personali: factori fizici, sociali, atitudinali și de mediu și factori din viața individului.

Toți acești factori sunt interconectați și se influențează reciproc așa cum sunt prezentați în figura 1:

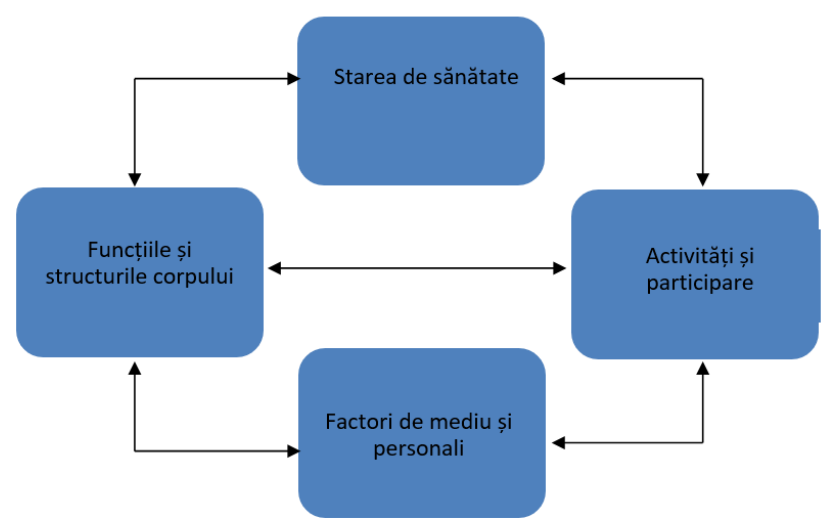

Fig.1: Reprezentarea schematică a interconectivității factorilor care contribuie la stabilirea obiectivelor în demersul terapeutic al despicăturilor facio-labio-palatine

ASHA propune cazul Mariei, pentru a ilustra abordarea despicăturii buzei și a palatului, din perspectiva ICF.

Starea de sănătate: Despicătură unilaterală a buzei și palatului operată, cu închidere adecvată a vălului palatin.

Datele de evaluare

-Funcțiile și structurile corpului

-Despicătură unilaterală a buzei și palatului

-Operată la 3 respectiv 12 luni 
- Închidere adecvată a vălului palatin

Vorbire: Limbajul receptiv și expresiv: mediu și peste mediu dezvoltat

Auzul (stare monitorizată în mod regulat)în limite normale, în ciuda istoricului de otită medie

Articulare și fonologie - erori de articulare compensatorii (sunete glotice pentru $\mathrm{p}, \mathrm{b}$, $\mathrm{t}, \mathrm{d}$; nazalizarea pentru s, z)

Activități și participare

Dificultăți de înțelegere de către ascultătorii mai puțin familiarizați

Participare redusă la activitățile desfășurate la clasă (de exemplu activitățile de grup sau de povestit)

Reticență de a se alătura jocului cu colegii de clasă și de a comunica verbal cu ascultătorii necunoscuți

\section{Factori de mediu și personali}

Maria are 4 ani. Este la grădiniță și are acces la ședințe de terapia limbajului

Are motivația pentru a-și îmbunătăți limbajul astfel încât ceilalți să o înțeleagă

Maria are o dorință puternică de a interacționa social cu colegii ei

Colegii o acceptă și încearcă să o includă pe Maria în jocuri

Are susținerea familiei, prietenilor și a profesorilor

\section{Raționamentul clinic}

Ce deficiențe afectează cel mai mult funcționarea în contextul actual, pe baza evaluării clinicianului și a raportului individual / al familiei?

Care activități sunt cele mai importante pentru individ în contextul actual?
Ce caracteristici personale / de mediu ajută sau împiedică participarea la activități sau situații în situația actuală?

Stabilirea obiectivelor (Obiectivele funcționale ale Mariei):

Obiective pe termen lung

Maria va participa la activitățile desfășurate împreună cu colegii ei și va fi înțeleasă atunci când vorbește cu prietenii și profesorii de la grădiniță și cu ascultătoti nefamiliarizați în contextele cotidiene de viață.

\section{Obiective pe termen scurt}

Maria va emite sunetele $p, b, t, d$ în toate pozițiile regăsite în cadrul cuvintelor, eliminând sunetele glotice în 90\% din situații în propoziții structurate în timpul terapiei individuale.

Maria va emite sunetele $s, z$ în toate pozițiile regăsite în cadrul cuvintelor, eliminând nazalizarea în 90\% din situații în propoziții structurate în timpul terapiei individuale.

Când va fi invitată de către colegii ei la activitățile de joc liber desfășurate în clasă, Maria va participa la conversații în cel puțin 4 din 5 oportunități pe săptămână, așa cum a menționat logopedul și profesorii.

\section{Studiu de caz}

D. s-a născut în luna martie, anul 2012, vârsta actuală fiind de 8 ani și 10 luni, având diagnosticul de cheilopalatoschizis (despicătură unilaterală totală stânga) constatat la naștere. Studiul de caz prezentat urmărește evoluția procesului de recuperare a lui D., de la naștere și până în prezent. 
Copilul este provenit din sarcină cu evoluţie normală, născut la termen, greutatea la naştere 3300 gr, Apgar=8, naștere prin cezariană. La naștere a fost diagnosticată cu cheilopalatoschizis, având 4 intervenţii chirurgicale până în prezent. Prima intervenție a fost de reparare a despicăturii labiale la vârsta de 8 luni, a doua intervenție a fost de reparare a despicăturii palatine care s-a realizat în jurul vârstei de 18 luni, a treia etapă chirurgicală, care a constat în reconstrucția structurii alveolare, s-a realizat în jurul vârstei de 30 de luni iar a patra intervenție s-a realizat după împlinirea vârstei de 5 ani și a constat în îndepărtarea unui dinte supranumerar apărut în zona despicăturii.

Încă de la vârsta de 5 săptămâni până la prima intervenție, fetița a purtat aparat ortodontic care a ajutat la alimentarea cu mai multă ușurință, modelarea narinei stângi și apropierea structurilor buzei și arcadei alveolare, evitând tensiunile care pot apărea în urma intervenției chirurgicale. De la 6 ani, D. poartă o placă de dilatare transversală fixată pe molarii maxilarului superior, utilizată în maxilarul îngust. De la 8 ani și 6 luni, D. poartă aparat dentar fix pe dinții maxilarului superior și „țepi ortodontici” („tongue tamers” sau „habit tamers”) pe doi dintre dinții din față, situați pe maxilarul inferior. Aceste instrumente ortodontice arată ca doi „minițepi” care ajută la antrenarea inconștientă a limbii și reamintește permanent limbii de a folosi palatul în momentul deglutiției, în loc să împingă dinții de jos, cauzând malocluzie (mashpeeortho.com). Aceste instrumente ortodontice care antrenează limba ajută și la antrenarea limbii în vederea emiterii corecte a consoanelor apico-dentale: $t, d$, $\mathrm{n}, \mathrm{s}, \mathrm{z}, \mathrm{t}, \mathrm{r}, \mathrm{l}$.

D. a început intervenția logopedică în jurul vârstei de 2 ani și 10 luni. La începutul terapiei, D. avea doar câteva cuvinte pe care le folosea și nu dorea să își folosească gura ca să vorbească, nu deschidea gura la cerere, când vorbea o făcea doar în șoaptă și nu dorea să repete dacă i se cerea. Având zona bucală afectată în urma intervențiilor chirurgicale, resimțindu-le ca o traumă a zonei, D. nu dădea voie nimănui să îi atingă zona feței. Din punct de vedere a limbajului receptiv, fetița avea o dezvoltare tipică.

D. a fost evaluată logopedic, cu scopul de a determina modalitățile cu care operează în comunicare, nivelul de dezvoltare a limbajului, capacitatea de imitare motrică (imitarea mişcărilor organelor de vorbire) şi verbală (imitarea sunetelor modelate de evaluator), răspunsul la întrebările evaluatorului, depistarea defectelor de pronunţie, în vederea propunerii unui plan de intervenţie logopedică.

La vârsta de 4 ani, copilul a fost diagnosticat cu deficit de cetoliză (deficit enzimatic congenital, boală metabolică) iar, din cauza despicăturii unilaterale totale, tot de la 4 ani prezintă episoade repetate de surditate de transmisie (factori de risc: palatoschizis).

Copilul a fost dus în colectivitate încă de la vârsta de un an, frecventând încă de atunci creșa, apoi grădinița cu program prelungit și ulterior școala. $\mathrm{Nu}$ a avut probleme de adaptare, fetiţa a avut şi are prieteni atât în colectivitate cât şi acasa. Îi place să coloreze, să răsfoiască paginile cărţilor colorate pentru copii şi practică tenis de 
câmp cu multă plăcere şi cu rezultate foarte bune.

Trăind într-un oraș mai mic, până la vârsta de 5 ani, D. a avut parte de mai mulți logopezi, aceștia părăsind orașul pentru a pune bazele unei cariere într-un oraș mai mare. Astfel, la 5 ani și o lună, D. a fost evaluată de un medic specialist psihiatrie pediatrică și un psihopedagog logoped. Fetița avea o dezvoltare fizică, afectivă și cognitivă corespunzătoare vârstei, producție grafică adecvată, personalitate în curs de structurare, dificultăți de pronunție a sunetelor cu substituirea acestora în interiorul cuvintelor, rinolalie; erori de articulare în vorbire cu omisiuni, distorsiuni și substituiri de sunete, inconsistențe în exprimarea sunetelor. În cadrul evaluării s-a aplicat interviul la care au răspuns părinții fetiței și aplicația Pași Prin Lumea Sunetelor (PPLS) pentru analiza pronunției. S-a examinat, de asemenea, aparatul fonoarticulator, capacitatea de a imita mișcările organelor de vorbire (motricitatea aparatului fonoarticulator), limbajul spontan manifestat în decursul evaluării, auzul fonematic, capacitatea de diferențiere fonematică.

\section{Rezultatele evaluării}

Aparatul fonoarticulator: după reconstrucţia aparatului fonoarticulator D. mai prezintă unele particularități care influenţează pronunţia în momentul de faţă: buza superioară rigidă, cu cicatrici, poziția vicioasă a incisivilor de pe maxilarul superior. Coordonare şi capacitate de imitare motrică şi verbală în curs de perfecţionare şi formare.
Pronunţia: vorbire dislalică, neinteligibilă, fetiţa fiind înţeleasă doar de cei din anturaj, foneme pronunţate deficitar, fie sunt distorsionate sau înlocuite. Auz fonematic, capacitate de diferențiere fonematică în curs de perfecţionare, pronunţia este uşor îmbunătăţită în vorbirea reflectată/după model. Alte aspecte surprinse în timpul evaluării: adăugiri sau simplificări ale cuvintelor în discordanţă cu vârsta cronologică.

Vocabularul: este corespunzător vârstei cronologice, D. cunoaşte o serie de noţiuni pe care le utilizează în vorbirea spontană, formulând enunţuri din mai multe cuvinte (3-4 cuvinte).

În momentul evaluării, D. nu diferenţiază tipurile de respiraţie orală de cea nazală, reuşește să sufle în instrumente muzicale şi baloane de săpun dar întâmpină greutăţi, adeseori fetiţa expira pe nas şi nu pe gură în totalitate. Diagnosticul logopedic este de dislalie polimorfă datorată tulburării organice la nivelul aparatului fonoarticulator (despicătură velo-palatină operată), hipoacuzie temporară (otită seroasă în curs de tratare). Se recomandă intervenţia logopedică în vederea mobilizării şi îmbunătăţirii motricităţii aparatului fonoarticulator, remedierea dislaliei şi dezvoltarea limbajului în conformitate cu nivelul de vârstă.

\section{Rezultate obtinute}

Tabel 1: Înregistrarea progresului prin rapoarte ale testelor de evaluare $\mathrm{cu}$ ajutorul aplicației Pași Prin Lumea Sunetelor 
Raport test PPLS, D., 5ani şi 1 lună

Răspunsuri corecte: $37 / 79=46,84 \%$

Sunete omise: $11 / 79=13,92 \%$

Sunete distorsionate: $3 / 79=3,8 \%$

Sunete înlocuite: $28 / 79=35,44 \%$

Consoane:

După modul de producere:

Oclusive (p,b,t,d,c,g): 10/18=55,56\%

Fricative (s,z,s,,j,f,v,h): 1/21=4,76\%

Africate (ţ, č, $\breve{\mathrm{g}}): 1 / 9=11,11 \%$

Nazale (m,n): $4 / 6=66,67 \%$

Sonante $(r, 1, m, n): 7 / 12=58,33 \%$

După locul de articulare:

Bilabiale (p,b,m): 6/9=66,67\%

Labiodentale (f,v): $\mathrm{o} / 6=0 \%$

Apico-dentale (t,d,n,s,z,ţ,r,l): 5/24=20,83\%

Alveolare (ş,j): $\mathrm{o} / 6=0 \%$

Palatale ( $\breve{c}, \breve{g}): 1 / 6=16,67 \%$

Velare (c,g): $6 / 6=100 \%$

Laringale $(\mathrm{h}): 1 / 3=33,33 \%$

Vocale

După zona de articulare

Anterioare (e,i): $5 / 6=83,33 \%$

Mediane (a,ă,î): $7 / 7=100 \%$

Posterioare (o,u): $6 / 6=100 \%$

După gradul de deschidere a cavităţii bucale

Deschise (a): $3 / 3=100 \%$

Semideschise (e,ă,o): 8/8=100\%

Închise $(\mathrm{i}, \hat{1}, \mathrm{u}): 7 / 8=87,5 \%$

După rotunjirea buzelor

Rotunjite (labiale) (o,u): 6/6=100\%

Nerotunjite (nelabiale) (e,i,a,ă,î): 12/13=92,31\%
Raport test PPLS, D., 8ani şi 10 luni

Răspunsuri corecte: $66 / 79=83,54 \%$

Sunete omise: o / $79=0,00 \%$

Sunete distorsionate: $12 / 79=15,19 \%$

Sunete înlocuite: $1 / 79=1,27 \%$

Consoane:

După modul de producere:

Oclusive (p,b, t, d,c,g): $16 / 18=88,89 \%$

Fricative $(\mathrm{s}, \mathrm{z}, \mathrm{ş}, \mathrm{j}, \mathrm{f}, \mathrm{v}, \mathrm{h}): 21 / 21=100,00 \%$

Africate $(t, \breve{c}, \breve{g}): 1 / 9=11,11 \%$

Nazale (m,n): 6 / $6=100,00 \%$

Sonante $(\mathrm{r}, \mathrm{l}, \mathrm{m}, \mathrm{n}): \mathrm{g} / \mathrm{12}=75, \mathrm{oo} \%$

După locul de articulare:

Bilabiale (p,b,m): $9 / 9=100,00 \%$

Labiodentale (f, v): $6 / 6=100,00 \%$

Apico-dentale (t, d, n, s,z, ț, r, l): $16 / 24=66,67 \%$

Alveolare (s, j): $6 / 6=100,00 \%$

Palatale (č, ğ): $1 / 6=16,67 \%$

Velare (c, g): $6 / 6=100,00 \%$

Laringale (h): $3 / 3=100,00 \%$

Vocale

După zona de articulare

Anterioare (e, i): $6 / 6=100,00 \%$

Mediane (a, ă, î): $7 / 7=100,00 \%$

Posterioare (o, u): 6 / $6=100,00 \%$

După gradul de deschidere a cavității bucale

Deschise (a): $3 / 3=100,00 \%$

Semideschise (e, ă, o): $8 / 8=100,00 \%$

Închise (i, î, u): 8 / $8=100,00 \%$

După rotunjirea buzelor

Rotunjite (labiale) (o, u): $6 / 6=100,00 \%$

Nerotunjite (nelabiale) (e, i, a, ă, î): $13 / 13=100,00 \%$
În ceea ce privește evaluarea inteligibilității vorbirii, folosind scala Speech Intelligibility Rating Scale-SIR (Bodea Hațegan, 2016), D. a pornit de la 1, ceea ce presupune că vorbirea acelei persoane este total neinteligibilă pentru ascultător iar în prezent este la 4, ceea ce înseamnă că vorbirea persoanei este inteligibilă în cea mai mare parte, chiar și pentru un vorbitor mai puțin familiarizat cu specificul articulator și fonator al unei persoane rinolalice, cu puține și mici excepții.

\section{Sedintele logopedice au vizat:}

Dezvoltarea respirației prin educarea respirației non-verbale și verbale:

Dezvoltarea respirației non-verbale (educarea echilibrului dintre inspirație și expirație - inspir adânc pe nas cu gura închisă, expirație pe gură);

Dezvoltarea respirației verbale (obținerea unei expirații mai lungi decât inspirația în timpul pronunției; vorbirea în expirațe fără efort și în mod ritmat). 
Dezvoltarea preachizițiilor: structuri senzorio-perceptive, schemă corporală, lateralitate, orientare spațio-temporală

Dezvoltarea abilităților de diferențiere auditiv-verbale

Dezvoltarea abilităților motorii generale și fine.

Un rol deosebit în terapia logopedică l-a ocupat mobilizarea orofacială și desensibilizarea la nivel facial. S-a realizat în mod regulat masaj la nivel facial și masare intraorală folosind periuțe diverse și kitul Z-Vibe și tehnica punctelor motorii propusă de Castillo Moralles. De asemenea, s-a efectuat miogimnastică și terapie miofuncțională prin imitarea în oglindă a exercițiilor propuse de către terapeut. Astfel, copilul poate percepe vizual poziția organelor de vorbire în timp ce se confruntă cu propriul model. În plus, $\mathrm{s}$-au folosit toți analizatorii pentru a percepe mult mai ușor caracteristicile sunetului și pentru a-l emite cât mai acurat (D. a fost încurajată să atingă gâtul adultului când acesta emite sunete; să atingă pieptul adultului când acesta inspiră și expiră puternic; să poată observa pe dosul palmei aerul expirat în timp ce adultul emite sunete precum: $f, v, h, s$, ș etc.).

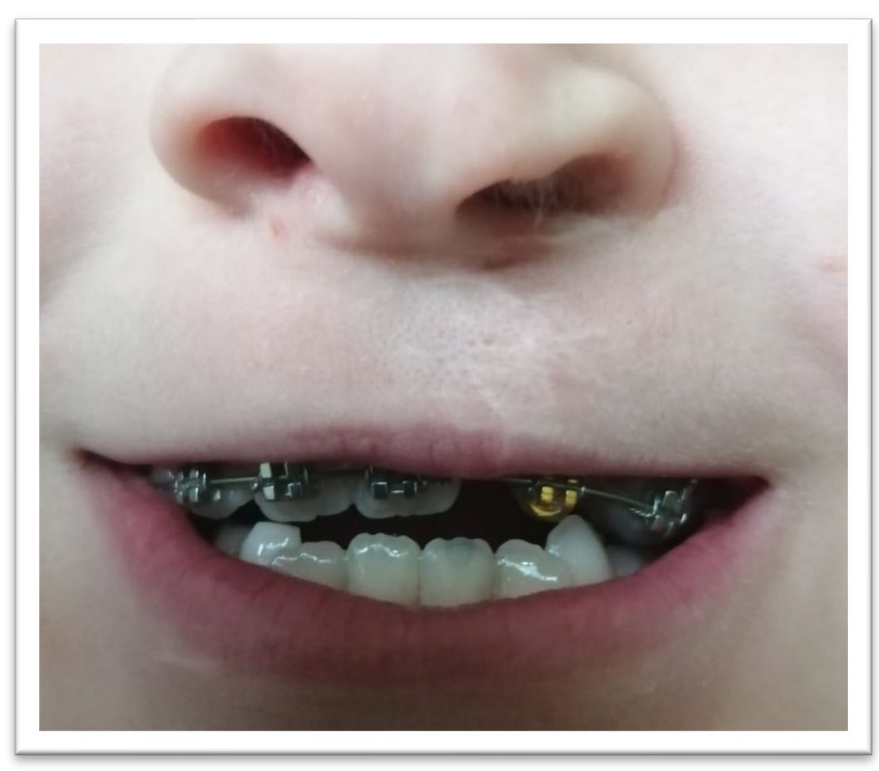

Fig.2: Imagine - Aparat ortodontic fix

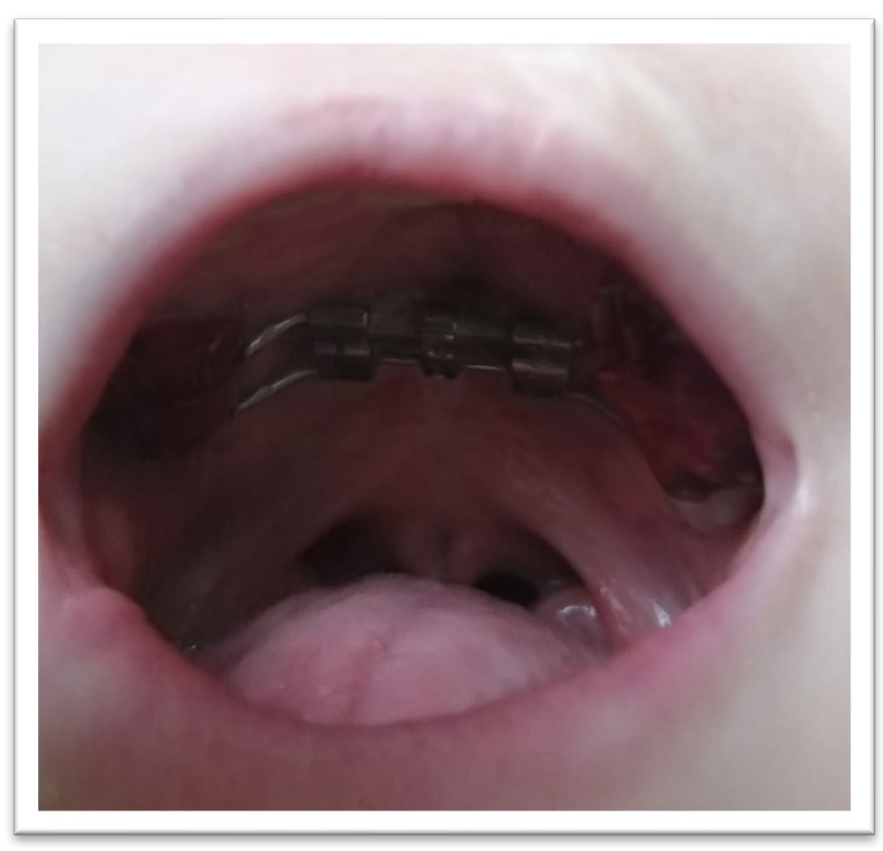

Fig. 3: Imagine - Placă de dilatare transversală fixă

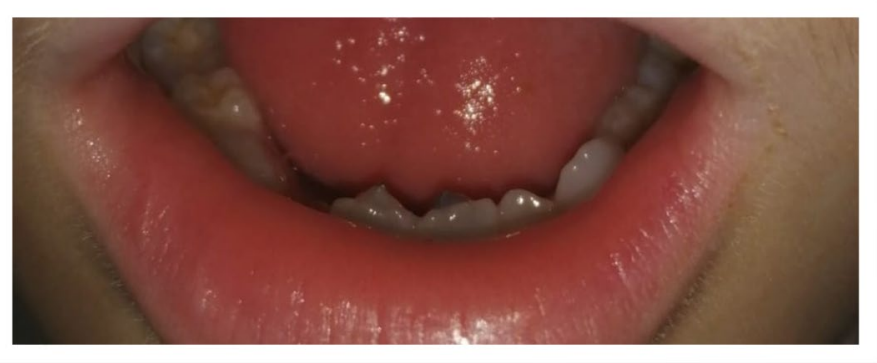

Fig. 4: Imagine „Tepi ortodontici” (Tongue tamers/Habit tamers) 


\section{Concluzii}

Durata procesului de recuperare a copilului cu despicătură facio-labiopalatină depinde de mai mulţi factori: nivelul dezvoltării intelectuale; vârsta la care se intervine; o premisă importantă este intervenția cât mai de timpuriu, când plasticitatea neuronală este mai mare; implicarea activă a părinţilor în procesul logopedic (terapia logopedică implică în principal implicarea părinţilor); gradul de implicare a copilului în realizarea activităţilor / exerciţiilor terapeutice.

Pentru înregistrarea succesului în munca logopedică, pe întreaga perioadă de recuperare şi tratament este necesară o strânsă colaborare cu familia copilului şi abordarea unei strategii comune, în privinţa modului de comunicare, a stimulării vorbirii şi a intelectului, a stimulării socializării şi a dorinţei copilului de a comunica, asigurarea unei dezvoltări psihice normale şi prevenirea instalării unor tulburări psihice sau de personalitate.

\section{Bibliografie}

Arosarena, O. A. (2007). Cleft lip and palate: Otolaryngologic Clinics of North America, vol. 40, no. 1, pp. 27-6o.

Bodea Hațegan, C. (2016). Terapia tulburărilor de limbaj. Structurilor deschise, Ed. Trei, București.

Bjork, A. (2007). Sutural growth of the upper face studied by the implant method: European Journal of Orthodontics i82-i88.

Boyne, P. J., Sands, N. R. (1972). Secondary bone grafting of residual alveolar and palatal clefts, Journal of Oral Surgery, vol. 30, no. 2, pp. 87-92.
Burlibaşa, C. (coord) (1999). Chirurgie orală și maxilo-facială, (Ed. aII-a), Ed. Medicală, București

Hurubeanu, L. (2002). Stomatologie şi chirurgie oro-maxilo-facială, Ed. Medicală a Universităţii „Iuliu Haţieganu", Cluj-Napoca.

Guţu, M. (1975). Logopedie, Universitatea Babeș-Bolyai, Cluj-Napoca, Uz intern

Katzel, E. B., Basile, P., Koltz, P. F., Marcus, J. R., Girotto, J. A. (2009). Current surgical practices in cleft care: cleft palate repair techniques and postoperative care, Plastic and Reconstructive Surgery: vol. 124, no. 3, pp. 899-900.

Kirschner, R. E., LaRossa, D. (200o). Cleft lip and palate: Otolaryngologic Clinics of North America, vol. 33, no. 6, pp. 1191-1215.

Kuijpers-Jagtman, A. M. (2006). The orthodontist, an essential partner in CLP treatment, B-ENT, vol. 2, no. 4, pp. 57-62.

Levy-Bercowski, D., DeLeon, E. Jr, Stockstill, J. W., Yu, J. C. (2011). Orthognathic cleftsurgical/orthodontic treatment, Seminars in Orthodontics, vol. 17, no. 3, pp. 197-206.

Meazzini, M.C. (2008). A Cephalometric Intercenter Comparison of Patients With Unilateral Cleft Lip and Palate: Analysis at 5 and 10 Years of Age and Long Term, The Cleft PalateCraniofacial Journal 45(6):654-60

Mercado, A., Vig, K. (2019). Orthodontic Principles in the Management of Orofacial Clefts 
Miloro, M., Larsen, P., Ghali, G. E. (2004). WaitePeterson's Principles of Oral and Maxillofacial Surgery:BC Decker, Ontario, Canada, 2 edition 2004.

Moldovan, I. (2006). Corectarea tulburărilor limbajului oral, Presa universitară clujeană, Cluj Napoca

Mureșan, R. (2015). Anatomia cavității bucale. Recuperarea disfagiei, note de curs

Salyer, K. E. (2001). Excellence in cleft lip and palate treatment, Journal of Craniofacial Surgery, vol. 12, no. 1, pp. 2-5.

Saperstein, E.L., Kennedy, D., Muliken, J.B., Padwa B., (2012).Facial growth in children with complete cleft of the primary palate and intact secondary palate: Oral Maxillofacial Journal 70:e66-e71.

Shaikh, D., Mercer, N. S., Sohan, K., Kyle, P., Soothill, P., (2001). Prenatal diagnosis of cleft lip and palate: British Journal of Plastic Surgery, vol. 54, no. 4, pp. 288-289.

Shetye, P. R., (2012). Presurgical infant orthopedics, The Journal of Craniofacial Surgery, vol. 23, no. 1, pp. 210-211.

Tote, R., Munteanu, S., Pascu, A., Purav, D., Stancu, D., Oruc, V., Komini, E., Melian, G., Zetu, I., (2014). Aspecte clinico-terapeutice ale despicăturilor labio-maxilo-palatine: date din lieratură, Romanian Journal of Medical and Dental Education, vol.3, issue 1, January-June 2014.

Vlachos, C. C. (1996). Orthodontic treatment for the cleft palate patient,
Seminars in Orthodontics, vol. 2, no. 3, pp.197-204.

Wyszynski, D.F. (2002). Cleft Lip and Palate: From Origin to Treatment: Oxford University Press.

http://www.dentalconceptstudio.ro/ro/In forma $\%$ C $8 \% 9$ Bii-pentru-

pacien $\% \mathrm{C} 8 \% 9 \mathrm{Bi} /$ Chirurgieortognat $\% \mathrm{C}_{4} \% 83$ Chirurgieortognat $\% \mathrm{C}_{4} \% 83-272$

https://www.intramed.ro/reabilitareapreoperatorie-sau-pregatirea-fizicainainte-de-operatie/

https://mashpeeortho.com/

https://

play.google.com/store/apps/details?id $=$ ppls.pps.com.ppl

1. Voluntar Asociația Autism Câmpia Turzii Profesor logoped CJRAE, Arad

Email: madalina.orian@gmail.com 